\title{
"A SEMPRE LEAL CIDADE DA PARAÍBA": CULTURAS HISTÓRICAS E CULTURAS POLÍTICAS EM UMA CAPITANIA DO IMPÉRIO PORTUGUÊS (SÉCULOS XVII E XVIII)
}

\author{
Mozart Vergetti de Menezes ${ }^{1}$ \\ José Inaldo Chaves Jr. ${ }^{2}$
}

\begin{abstract}
As representações, verdadeiras ou falsas, de um grupo social acerca do seu passado podem ser tão relevantes para explicar seu comportamento quanto seus interesses materiais
\end{abstract}

Evaldo Cabral de Mello

\section{1}

No ano de 1661, mais precisamente no dia três de maio, o rebuliço se instaurara entre os edis na câmara da cidade da Paraíba. A convocação inesperada era para tornar pública uma carta do general governador de Pernambuco, Francisco de Brito Freire, em que dizia caber-lhe a jurisdição civil e militar da capitania da Paraíba. ${ }^{3}$ Na missiva, alertava o general que mandava cerca de duzentos soldados por terra e outros tantos por mar, comandados pelo capitão olindense João do Rego Barros, para se instalarem e guarnecerem as praças fortes da Paraíba.

Revoltados com o que determinava Brito Freire, os vereadores deram voz ao mundo sobre o deslocamento das tropas de Pernambuco. Rapidamente a nova correu pelos quatro cantos da cidade da Paraíba e, em poucos dias, se teve conhecimento que a investida de Brito Freire tinha voos maiores e ganhava proporções alarmantes. A capitania de Itamaracá fora tomada. Contígua à de Pernambuco, de lá veio a notícia de que seu capitão-mor fora encarcerado na fortaleza do Mar. Ordens com o mesmo teor também foram expedidas para o Rio Grande e o Ceará. Na cidade Paraíba, contudo, as tentativas do general sofreram alguns reveses. ${ }^{4}$

Para Brito Freire, sua ação se justificava porque estando a Paraíba independente em meio às outras capitanias que lhes ficariam anexadas, poderia dar acolhimento a quantos facinorosos e salteadores que ali se recolhessem. ${ }^{5}$ Aliados à segurança, fatores econômicos também permeavam o movimento de anexação, principalmente no que se refere a baixa geral no preço do açúcar na Europa $e$ a consequente diminuição nas arrematações dos impostos. Incorporar, então, a receita da Paraíba seria uma ideia bem acolhida entre as classes senhoriais de Pernambuco, já que a falta de obediência só aumentaria as despesas da provedoria pernambucana. Neste sentido, vale lembrar que a Paraíba

\footnotetext{
${ }^{1}$ Mozart Vergetti de Menezes é professor Associado do Departamento de História da Universidade Federal da Paraíba (EFPB. Possui graduação e mestra em História pela UFPE, e doutorado no Programa de História Econômica da USP. É autor do livro Colonialismo em Ação. Fiscalismo, Economia e Sociedade na Capitania da Paraíba (1647-1755) (João Pessoa, Editora da UFPB, 2012) e autor e co-organizador de Ensaios sobre a América Portuguesa (Editora Universitária / UFPB, 2009).

${ }^{2}$ José Inaldo Chaves Jr. é professor adjunto do Departamento de História da Universidade de Brasília (UnB). Possui graduação em História pela UFPB, mestrado e doutorado em História Social pela UFF. É autor do livro As duras cadeias de hum governo subordinado: poder e sociedade na Paraíba colonial (c.1756-c.1799) (Curitiba: CRV, 2018) e autor e coorganizador de Colonialidades: governos, gentes e territórios na América Ibérica (Curitiba: Editora Prismas, 2017).

${ }^{3}$ 1661, novembro, 12, Lisboa; CONSULTA (cópia) do Conselho Ultramarino, à rainha regente D. Luísa de Gusmão, sobre as diferenças entre o capitão-mor da Paraíba, Matias de Albuquerque Maranhão, e o governador de Pernambuco, Francisco de Brito Freire, no tocante à jurisdição de suas capitanias, e o que sobre isto escreveram o governador e capitão-general do Brasil, Francisco Barreto, e os oficiais da Câmara da Paraíba. Anexo: 2 docs. AHU-Paraíba, cx. 1 AHU_CU_014, Cx. 1, D. 47. Lê-se: ARQUIVO HISTÓRICO ULTRAMARINO CONSELHO ULTRAMARINO_014[Paraíba], Caixa 1, Documento 47.

${ }^{4}$ AHU-Paraíba, cx. 1 AHU CU 014, Cx. 1, D. 47.

${ }^{5}$ AHU-Paraíba, cx. 1 AHU_CU-014, Cx. 1, D. 47. 
estava desobrigada de prestar contas das suas despesas pelo socorro que Pernambuco lhe devia de fazendas, munições e armas em compensação pela tática de terra arrasada a que foi submetida para se evitar a reacomodação de tropas holandesas naquele espaço. ${ }^{6}$

$\mathrm{Na}$ Paraíba, os destroços da Guerra da Liberdade Divina ainda deixavam seus vestígios tanto nos prédios públicos, igrejas e casas de morada, como na vida de muitas pessoas que haviam perdido seus entes. A elite senhorial que clamava ao rei por isenções de impostos e que vivia sem recursos para adquirir escravizados negros em número suficiente para tocar seus engenhos e cultivar os partidos de cana, via-se cada vez mais dependente das repartições de índios aldeados. ${ }^{7}$ Tais índios que trabalhavam por jornais, além da lide dos engenhos cumpriam também as tarefas junto aos empreiteiros, como levantar e consertar as edificações da urbe, como calçadas, pontes, igrejas, além de dar sustentação às intermináveis reformas da fortaleza do Cabedelo. Registre-se, contudo, que para cumprirem esses trabalhos os índios na Paraíba estavam divididos em três aldeias, uma sob o comando dos frades beneditinos $e$ as outras com um administrador militar diretamente sujeito às ordens do capitão-mor governador. Assim, caso se procedesse a anexação, eles passariam a responder ao general de Pernambuco, podendo sofrer deslocamentos e deixar ainda mais grave a falta de braços na Paraíba. ${ }^{8}$

Dito isto, havia um outro problema para ser resolvido: para onde seriam deslocadas as tropas que estavam perpetuadas na Paraíba desde o tempo do governo de João Fernandes Vieira? Essa gente que não fora desmobilizada e que não se direcionou para as terras do sertão, no intuito de guerrear contra nações indígenas e construir a "civilização do couro", segundo conhecida alcunha de Capistrano de Abreu, foi ficando e se arrumando de alguma forma. ${ }^{9} \mathrm{Na}$ sua grande maioria ela passou a constituir famílias, gerando como "filhos da terra" uma população mestiça e livre que, plantando roça e se ocupando de atividades cotidianas como pedreiros, calafates, pescadores, foi se espraiando nas áreas do litoral ou próximas das várzeas e em torno da capital. ${ }^{10}$

Apoiada então neste segmento populacional, a elite senhorial paraibana pressionou o capitão-mor e governador, Mathias Albuquerque Maranhão, através de uma representação do Senado da câmara da cidade da Paraíba, em nome do povo da capitania, para que se dirigisse a sua Alteza Real e a sensibilizasse sobre as "sem razões", ou seja, as insanidades de Brito Freire de querer criar uma guerra civil entre as capitanias. Tencionada, a população da Paraíba ameaçou ir às armas para não se entregar tão facilmente às ordens do general. ${ }^{11}$

A carta enviada por Maranhão ao rei, muito embora tenha seu lado irônico ao acusar o general de Pernambuco de "querer imbicar" consigo e de estar agindo como "um mancebo apaixonado", por um simples capricho de querer reviver tal e qual o seu antecessor André Vidal de Negreiros, que teve, pela pessoa e não pelo cargo, prerrogativas de comando supracapitanias, ${ }^{12}$ descreve o âmago dos

\footnotetext{
${ }^{6}$ Em carta dirigida ao rei, em 1656, diziam os oficiais da câmara da Paraíba que "tomando as armas juntamente com os moradores da capitania de Pernambuco e vendo que (...) nem um nem outro poderiam reduzir o grande poder do inimigo, se deliberaram como fiéis vassalos de $\mathrm{V}$. Majestade de se retirarem para Pernambuco (...) queimaram e arrasaram suas casas, engenhos e canaviais de açúcar (...0". Cf. 1657, julho, 12, Lisboa, CONSULTA do Conselho Ultramarino, ao rei D. Afonso VI, sobre a carta dos oficiais da Câmara e povo da Paraíba em que solicitam ajuda de Pernambuco para o sustento dos soldados existentes na capitania, por se encontrarem impossibilitados com suas fazendas e engenhos, danificados em decorrência da luta contra os holandeses. AHU ACL CU 014, Cx.1, D. 40.

${ }^{7}$ 1657, agosto, 12, Paraíba CARTA (cópia) dos oficiais da Câmara da Paraíba, ao rei [D. Afonso VI], sobre a taxação dos preços do açúcar e a situação de miséria em que se encontram os moradores da capitania. AHU_ACL_CU_014, Cx. 1, D. 41.

${ }^{8}$ 1675, outubro, 7, Lisboa CONSULTA do Conselho Ultramarino, ao príncipe regente D. Pedro, sobre a representação dos moradores da Paraíba para conservarem os índios em suas aldeias, podendo, assim, usá-los em suas lavouras e fábricas de engenhos, lenhas e outros serviços, na falta de escravos de Angola. AHU_ACL_CU_014, Cx. 1, D. 95.

${ }^{9}$ Em 1661, a câmara da Cidade da Paraíba pedira ao governador, Mathias de Albüquerque Maranhão, "que não consentisse que ellas [as tropas acantonadas] se retirassem, por serem a maior parte dos soldados filhos, parentes e amigos dos moradores desta praça; onde como tais estavão accomodados, e socorridos". AHU_ACL_CU_014, Cx.1, D. 40.

${ }^{10}$ A respeito do destino das tropas luso-brasileiras após a debacle dos batavos e o povoamento dos sertões das capitanias do Norte, cf. SILVA, Kalina Vanderlei Paiva da. "Nas solidões vastas e assustadoras" - os pobres do açúcar e a conquista do sertão de Pernambuco nos séculos XVII e XVIII. Tese (Doutorado em História), Universidade Federal de Pernambuco, Recife, 2003.

${ }^{11}$ AHU_ACL_CU_014, Cx. 1, D. 47.

${ }^{12}$ Sobre o caso de André Vidal de Negreiros, que em 1667 recebeu poderes ampliados e específicos de vice-rei e capitãogeneral do Brasil, cf. ACIOLI, Vera Lúcia Costa. Jurisdição e conflitos: aspectos da administração colonial, Pernambuco século XVII. Recife: Editora Universitária da UFPE, 1997, p. 81-103; Documentos Históricos da Biblioteca Nacional, vol. X, 352 SÆCUlUM - REVISTA DE HistóRIa [39]; João Pessoa, jul./dez. 2018.
} 
sentimentos que contaminavam os camarários da cidade da Paraíba. A rigor, a missiva espelhava os argumentos de fundo contidos na representação da câmara endereçada ao próprio Maranhão. ${ }^{13}$

Cônscios de sua historicidade, os edis esboçaram aquilo que acreditavam ser seus espaços vitais de conquista $e$ a base material do seu poder e autogoverno, identificando nas amarras propostas por imposição de Brito Freire uma verdadeira violação dos pactos entre a Coroa e os seus leais súditos da cidade da Paraíba por meio do costume e do direito natural das gentes. ${ }^{14}$ Introduziram, então, uma toponímia da política local baseada na manutenção dos privilégios $e$ isenções dos primeiros conquistadores, que seria revisitada sempre que se viram ameaçados com a perda da autonomia da capitania.

Primeiro, que a Paraíba nascera como uma capitania Real, diferentemente da de Pernambuco que carregava a mácula de ter sido uma capitania privada, de donatário; segundo, que a sua cabeça fora constituída desde os primórdios como cidade real e não vila, como era, até então, Olinda; terceiro, que todas as capitanias do Estado do Brasil estavam sujeitas, inclusive Pernambuco, apenas ao governador-geral e vice-rei na Bahia - maior representante régio na conquista ${ }^{15}$; e, quarto, que a manutenção da independência da Paraíba seria condição sine qua non para pôr freios às perturbações vindas de Pernambuco, cujos habitantes eram, desde a Restauração, reputados por soberbos e instáveis. ${ }^{16}$

Tal discurso, a princípio de cunho militar e político-administrativo, acabou por inaugurar também uma outra visão identitária sobre aquele território colonial, ajustando-se com o contexto do pós-guerra quando da rearrumação dos poderes locais e do centro nas capitanias do Norte e, por certo, senão contrastava, recuperava subsidiariamente alguns dos vaticínios de Ambrósio Fernandes Brandão de início dos Seiscentos. Dizia então o senhor de engenho na Paraíba que, senão estivesse o porto paraibano tão contíguo com o de Pernambuco, a cidade da Paraíba teria melhor sorte. ${ }^{17}$

Doravante, quanto ao contexto do pós-restauração, o que nos é substancial é saber que a ação de Brito Freire frutificou uma ruptura decisiva na percepção da classe senhorial das várzeas do rio

1929, p. 10ss. Para uma síntese recente da questão, cf. CHAVES JR., José Inaldo. As capitanias de Pernambuco e a construção dos territórios e das jurisdições na América portuguesa (século XVIII). Tese (Doutorado em História), Universidade Federal Fluminense, Niterói, 2017, p. 73ss.

${ }^{13}$ AHU_ACL_CU_014, Cx. 1, D. 47.

${ }^{14}$ Sobre os pactualismos e a revolta nas culturas políticas do Portugal moderno e suas conquistas, cf. FIGUEIREDO, Luciano Raposo de. Narrativas das rebeliões - linguagem política e ideias radicais na América portuguesa moderna. Revista da Universidade de São Paulo, São Paulo, v.111, mar/mai, p. 6-27, 2003; FIGUEIREDO, Luciano R. Maquiavelianas Brasileiras: dissimulação, ideias políticas e revoltas coloniais (Portugal, séculos XVII e XVIII). Tempo, Niterói, v.20, p. 1-24, 2014; ver ainda FRAGOSO, João; GOUVÊA, Maria de Fátima; BICALHO, Maria Fernanda. Uma leitura do Brasil Colonial. Bases da materialidade e da governabilidade no Império. Penelópe, n. 23, 2000, p. 67-88.

${ }^{15}$ Sobre o papel do governador-geral do Estado do Brasil e, nalguns momentos, vice-rei como "ministro do rei" $e$ encarregado de funções governativas de "topo", Francisco Carlos Cardoso Cosentino esclarece que "A posição cimeira desse cargo dava aos seus detentores um status de ministro que de acordo com Bluteau era 'aquele de quem o Príncipe fia a administração de cousas concernentes ao governo', 'era alguém em quem o rei confiava, ao ponto de lhe entregar tarefas governativas de topo'”. COSENTINO, Francisco Carlos Cardoso. Governo-Geral do Estado do Brasil: governação, jurisdições e conflitos (séculos XVI e XVII). In: FRAGOSO, João \& GOUVÊA, Fátima (org.). Na Trama das Redes. Política e negócios no império português, séculos XVI-XVIII. Rio de Janeiro: Civilização Brasileira, 2010, p. 409. Do mesmo autor, cf. sobretudo COSENTINO, Francisco C. C. Governadores Gerais do Estado do Brasil (séculos XVI-XVII): ofício, regimentos, governação e trajetórias. São Paulo: Annablume, 2009.

${ }^{16}$ AHU CU 014, Cx. 1, D. 47. Sobre a má fama dos vassalos de Pernambuco, cf. MELLO, Evaldo Cabral de. Rubro veio: o imaginário da restauração pernambucana. 3 ed. São Paulo: Alameda, 2008, p. 96.

${ }^{17}$ Em 1617, Ambrósio Fernandes Brandão colocaria na ordem do dia o tema das relações comerciais entre a Paraíba $e$ Pernambuco, associando, inclusive, o parco crescimento daquela à sua danosa aproximação para com a opulenta vizinha. Nos Diálogos das Grandezas do Brasil, de Brandão, lê-se: "E que dano é o que faz a Capitania de Pernambuco a estoutra [sic] com a sua vizinhança?", perguntou Alviano. A resposta de Brandônio, protagonista fictício dos Diálogos, fora enfática: "Antes isso é causa de não haver ido ela [a Paraíba] em mais crescimento: porque como tem Pernambuco tão chegado, os seus moradores se costumam prover dela das cousas de que têm necessidade, fazendo levar, para esse efeito, muitos açúcares que comutam pelo que compram, com o que engrandecem cada vez mais a Capitania de Pernambuco e diminuem na sua. $\mathrm{E}$ a razão é porque deixam de vir as naus a ela, que viriam se os seus moradores esperassem por elas para se haverem de prover do que lhes fosse necessário, e para esse efeito reservassem os seus açúcares, tendo-os prestes para com eles se carregarem as ditas naus. Mas como estão já providos de Pernambuco, aonde têm despendido os seus açúcares, as naus que vêm ao seu porto não podem dar a saída que quiseram às fazendas que trazem, nem menos carregarem com a brevidade que lhes era necessária, e por este respeito vêm poucas, sendo a Capitania capaz de carregar em cada um ano vinte naus" (BRANDÃO, Ambrósio Fernandes. Diálogos das Grandezas do Brasil. Org. e introdução de José Antônio Gonsalves de Mello; prefácio de Leonardo Dantas. 3 ed. integral segundo apógrafo de Leiden. Recife: FUNDAJ, Ed. Massangana, 1997, p. 25). 
Paraíba, que identificara na correlação de forças entre as capitanias não mais uma questão meramente de estratégia econômico-portuária (até então vista como bem sucedida, por sinal), antes também, como dissemos, de rateio do aparelho militar e político-administrativo, i.é., de concorrência pelo governo local. Os inimigos, como bem expressou Mathias Maranhão, se encontravam, a partir dali, não só das portas a fora, mas, igualmente, das portas adentro.

Este assunto também ecoa nos trabalhos da historiadora Regina Célia Gonçalves. Referindo-se à formação da elite política da capitania da Paraíba nos séculos XVI e XVII, Gonçalves recorda que até a invasão dos neerlandeses, para o território compreendido pelas capitanias de Pernambuco, Itamaracá e Paraíba, fazia muito sentido falar em um tronco familiar único, cujo controle financeiro e políticoadministrativo se daria através dos interesses da agromanufatura açucareira sediados em Olinda. E fora exatamente de Pernambuco, menos de Itamaracá, donde partira a maioria dos grupos de conquistadores que enxergava nas várzeas do rio Paraíba a possibilidade de sua reprodução social por meio da expansão dos negócios do açúcar, do cativeiro de índios e do status de homens bons. Todavia, e ainda seguindo os passos de Regina Célia Gonçalves,

(...) tal equilíbrio foi completamente comprometido durante a presença dos holandeses e, principalmente, após o período de guerra pós-restauração. O fracionamento provocado por diferentes posições adotadas pelas várias famílias, e até mesmo no interior das famílias por seus diversos membros, durante as fases de resistência à invasão, da ocupação propriamente dita e da restauração, explodiria com a querela dos engenhos. ${ }^{18}$

É obvio que a hegemonia mercatória com o Atlântico pelas praças de Pernambuco - primeiro Olinda e depois Recife -, conduzindo o giro mercantil e a concentração de capitais nas capitanias do Norte, se eternizou até os fins dos tempos coloniais e além. ${ }^{19}$ Entretanto, parece-nos que o post-bellum e a disputa pelo butim da guerra brasílica pusera irremediavelmente em lados opostos elites locais que tiveram um berço comum na açurocracia olindense do século $\mathrm{XVI} \cdot{ }^{20} \mathrm{O}$ resultado fora que esse processo desengatara a composição de outras representações do poder local - uma outra cultura política, igualmente aos moldes do Antigo Regime ibérico, mas portadora de novas definições de naturalidade e vizinhança, que passara a pleitear espaços de poder específicos e separados com relação à capitania vizinha e que se expressou na toponímia manifesta pela câmara da cidade da Paraíba desde então. ${ }^{21}$

\footnotetext{
${ }^{18}$ GONÇALVES, Regina Célia. Guerras e açúcares: política e economia na Capitania da Parayba, 1585-1630. Bauru: EDUSC, 2007, p. 52.

${ }^{19}$ A esse respeito, cf. OLIVEIRA, Elza Régis de. A Paraíba na crise do século XVIII: subordinação e autonomia (1755-1799). 2 ed. João Pessoa: Editora Universitária/UFPB, 2007; SOUZA, George Félix Cabral de. Tratos e Mofatras: o grupo mercantil do Recife colonial (c.1654-c.1759). Recife: Editora Universitária/UFPE, 2012; e DIAS, Thiago Alves. Monopólio Indireto: Colonização Mercantil no Norte do Estado do Brasil (c. 1710 - c. 1780). Tese (Doutorado em História Econômica), Universidade de São Paulo, São Paulo, 2017; em uma outra perspectiva, cf. CHAVES JR., José Inaldo. As duras cadeias de hum governo subordinado: poder e sociedade na Paraíba colonial (c.1756-c.1799). Curitiba: Editora CRV, 2017.

${ }^{20}$ Sobre o butim da guerra contra os neerlandeses, cf. MENEZES, Mozart Vergetti de. Colonialismo em ação: fiscalismo, economia e sociedade na Capitania da Paraíba (1647-1755). Tese (Doutorado em História Econômica), Universidade de São Paulo, São Paulo, 2005.

${ }^{21}$ Compreendemos e aplicamos a categoria "cultura política" como "(...) um sistema de representações, complexo $e$ heterogêneo, mas capaz permitir a compreensão dos sentidos que um determinado grupo (cujo tamanho pode variar) atribui a uma dada realidade social, em determinado momento e lugar". Ademais, é importante ressaltar a articulação com as culturas históricas, como propôs Ângela de Castro Gomes, isto é, quase sempre culturas políticas relacionam-se com dadas leituras do passado “(...) histórico, mítico ou ambos - que conota[m] positiva ou negativamente períodos, personagens, eventos e textos referenciais. Essa[s] leitura[s] do passado também envolveria[m] um 'enredo' - uma narrativa - do próprio passado, podendo-se então conformar uma cultura histórica articulada a uma cultura política". Ocioso ressaltar a diversidade de culturas políticas existentes em qualquer sociedade. "Competindo entre si, completando-se, entrando em rota de colisão, sua multiplicidade não impediria, contudo, a possibilidade de emergência de uma cultura política dominante em certas conjunturas específicas". GOMES, Ângela de Castro. Cultura política e cultura histórica no Estado Novo. In: ABREU, Martha; SOIHET, Rachel \& GONTIJO, Rebeca. Cultura política e leituras do passado: historiografia e ensino de história. Rio de Janeiro: Civilização Brasileira, 2007, p. 47-48. A respeito do conceito de "cultura histórica", cf. também o sugestivo artigo de FLORES, Élio Chaves. Dos feitos e dos ditos: história e cultura histórica. Saeculum - Revista de História [16]. João Pessoa, jan/jun, 2007.
} 
Deste modo, o apego às representações da tradição corporativa e pluralista do Antigo Regime português e sua atualização na América escravista por parte dos conquistadores foram buscados pela elite camarária da Paraíba tanto no que compete aos arraigados valores aristocráticos daquela sociedade colonial - prerrogativa nobiliárquica fundada sobre a conquista com sangue e fazendas e na posse de terras e homens - como nas demandas político-administrativas - em particular, a expectativa da retribuição pelo serviço prestado à Coroa e materializada na garantia do controle local sobre o governo da capitania. ${ }^{22}$

Destarte, o resultado do imbróglio criado por Brito Freire levou o rei D. João IV, em 12 de novembro de 1661, ordenar que deixasse claro ao governador de Pernambuco que a Paraíba, bem como as outras capitanias não lhe eram anexas e que, pelo tempo que fosse necessário, não deixasse de prover a Paraíba de infantaria enquanto não houvesse renda suficiente para a sustentar. ${ }^{23}$ Com a recusa da Coroa em corroborar com a ambição de Brito Freire, a elite senhorial da Paraíba tinham vencido a primeira batalha de uma longa guerra fraticida.

\section{4}

À 27 de maio de 1744 veio a óbito o governador e capitão-mor da Paraíba Pedro Monteiro de Macedo. De pronto, os camaristas da cidade deram conta de se autonomearem ao que chamavam de Governo Político da capitania e de reconhecerem no cargo de governador das armas o capitão da infantaria paga, Francisco de Mello Muniz. Tal arranjo deveria durar até que se procedesse, no Conselho Ultramarino, o rito de recolha das cartas de serviços dos opositores dispostos a assumir o governo da capitania e, a partir da Consulta ao rei, dar-se finalmente a escolha do novo governador. ${ }^{24}$

Porém, para surpresa e arrepio dos oficiais da câmara, se encontrava na Paraíba o tenente e mestre de campo general e engenheiro da capitania de Pernambuco, Manuel Xavier Bernardo, que havia sido mandado pelo rei para inspecionar as obras de reparação e construção das fortalezas. Dessa feita, o mestre de campo, movido pelo fato de possuir na hierarquia militar maior patente que o capitão de infantaria, requereu a Francisco de Mello Muniz o governo das armas. Indeciso quanto a ordem de precedência, Francisco Muniz não deixou por menos e pediu um tempo para questionar o governador de Pernambuco se teria, Manuel Xavier Bernardo, direito para comandar as armas na Paraíba, afinal, apesar de estar a serviço de sua Majestade, atuava fora de sua jurisdição. Sem titubeio, o governador de Pernambuco, Henrique Luiz Pereira Freire, respondeu que sim: tocava ao mestre de campo assumir o dito posto! ${ }^{25}$

O alarido que esta resposta provocou na câmara da Paraíba foi ouvido em Pernambuco, Bahia e Lisboa. Imediatamente, já em cinco de junho, os vereadores despacharam uma carta para o Governo Geral, na Bahia, com o pedido de nomeação de um governador interino. O atendimento ao pleito foi imediato, pois a informação sobre o falecimento do antigo governador havia chegado aos ouvidos do vice-rei antes mesmo do protocolo oficial. Neste sentido, fora então nomeado para a capitania da Paraíba o mestre de campo do terço de infantaria paga da cidade do Recife, João Lobo de Lacerda, que tomou posse do posto em seis de agosto. E, segundo o próprio Lacerda, ao ter chegado à Paraíba dois dias antes da posse, pôde tomar conhecimento de que ainda havia algumas alterações na capitania sobre a quem caberia realmente a responsabilidade do seu governo e procurou acalmar os

\footnotetext{
${ }^{22}$ Acerca do corporativismo e pluralismo jurídico e político do Antigo Regime português, cf. HESPANHA, António Manuel. Antigo Regime nos Trópicos? Um debate sobre o modelo político do império colonial português. In: FRAGOSO \& GOUVÊA (org.). Na trama das redes...; e o clássico do mesmo autor, HESPANHA, António Manuel. As vésperas do Leviathan. Instituições e poder político. Portugal: século XVII. Coimbra: Livraria Almedina, 1994. Para uma síntese do topoi das nobrezas da terra na América portuguesa, cf. BICALHO, Maria Fernanda B.. Elites coloniais: a nobreza da terra e o governo das conquistas. História e historiografia. In: MONTEIRO, Nuno Gonçalo F.; CARDIM, Pedro \& CUNHA, Mafalda Soares da (org.). Optima Pars. Elites Ibero-Americanas do Antigo Regime. Lisboa: ICS, 2005. A cultura política dos tempos modernos, considerando particularmente a experiência portuguesa, foi tratada por GOUVEA, Maria de Fátima Silva \& SANTOS, Marília Nogueira dos. Cultura política na dinâmica das redes imperiais portuguesas, séculos XVII e XVIII. In: ABREU; SOHEIT \& GONTIJO, Cultura política e leituras do passado..., p. 93.

${ }^{23}$ AHU ACL CU 014, Cx. 1, D. 47.

${ }^{24} 1745$, outubro, 11, Paraíba. CONSULTA do Conselho Ultramarino, ao rei D. João V, sobre as dúvidas que os oficiais da câmara da Paraíba tiveram na sucessão do governo da sua capitania, quando do falecimento do capitão-mor, Pedro Monteiro de Macedo. Anexo: 5 docs. AHU ACL CU 014, Cx. 13, D. 1123.

${ }^{25}$ AHU ACL CU 014, Cx. 13, D. 1123.
} 
ânimos. ${ }^{26}$

Tais alterações eram provenientes de incertezas e paranoias que foram se revelando aos poucos. Uma delas se ligava a dúvida quanto ao rito que deveria ser seguido para preenchimento do vácuo do poder existente com a morte do governador, pois, apesar da tomada de posição da câmara em instalar-se no governo político e o maior cabo de guerra no governo das armas, nada havia de segurança legal nisto, afinal baseava-se apenas na experiência vivida anos atrás, quando da morte do governador Antônio Velho Coelho, em 1719. Este recurso criado pela câmara só seria realmente oficializado no ano seguinte, numa consulta ao rei, em outubro de 1745 , quando passou a servir de modelo para casos semelhantes.

Entretanto, o que dava ares de dramaticidade e pendulava a política local entre o acerto e o erro na solução encontrada pelos vereadores, estava na declarada suscetibilidade de verem-se incapazes de barrar os artifícios dos generais governadores de Pernambuco de quererem subordinar a capitania da Paraíba às suas ordens: seria a admissão do nome do mestre de campo engenheiro sinal disso? ${ }^{27}$ Perspicazes, os edis da Paraíba encaminharam duas missivas. Uma para o governador de Pernambuco na qual levantam uma série de capítulos sobre os poderes que lhes cabiam como possuidores do governo político da capitania e outra para o rei, denunciando os riscos de se tornarem uma capitania anexa a Pernambuco. ${ }^{28}$

No caso da carta dirigida ao governador da capitania vizinha, o objetivo não buscava apenas balizar as ações que lhes seriam permitidas na posse do governo político, mas, principalmente, fazer com que o general, ao respondê-las, reconhecesse e legitimasse a câmara no dito governo. $\mathrm{O}$ estratagema consistiu em formular onze questões com ares de subserviência que iriam desde as que foram respondidas positivamente, como a indagação de pertencer ou não a eles o governo político, de poderem doar datas de terras em sesmarias, de proverem postos milicianos e de nomearem oficial da décima ou secretário do governo; e aquelas que foram peremptoriamente negadas, como as que questionavam ser possível ou não revogarem certos atos do governador defunto, tomados de forma indevida por irem de encontro à jurisdição do ouvidor. ${ }^{29}$

A outra carta, e é esta a que mais nos interessa, endereçada a Sua Majestade, externava a preocupação de serem sempre os governadores de Pernambuco bastante cuidadosos com os seus interesses em subordinar a capitania da Paraíba. E que o atual governador vizinho, por estar a vivenciar um momento de concertação do poder na Paraíba, dado o infortúnio de Pedro Monteiro de Macedo, poderia muito bem querer lançar mão dessa diligência. ${ }^{30}$

Ao usarem a palavra sempre, os camarários fizeram uso assertivo dos passados e das memórias daquilo que pretendera Brito Freire, acionando, a contrapelo, a toponímia nativista em defesa da condição de homens bons desde a conquista da terra. Tratava-se de uma identidade caracterizada por laços muito objetivos de pertença a uma comunidade local da qual eram "senhores naturais" sob o beneplácito do rei - uma "pátria" no sentido moderno e ibérico apontado por António Manuel Hespanha e Tamar Herzog - e com garantias do autogoverno e das condições privilegiadas de constituição patrimonial e engrandecimento social. ${ }^{31}$ Por isso, recordaram ao rei a cantilena com ares

\footnotetext{
${ }^{26}$ AHU ACL CU 014, Cx. 13, D. 1123.

${ }^{27}$ AHU_ACL_CU_014, Cx. 13, D. 1123.

${ }^{28}$ AHU_ACL_CU_014, Cx. 13, D. 1123.

${ }^{29}$ AHU_ACL_CU_014, Cx. 13, D. 1123.

${ }^{30} 1744$, outubro, 15, Paraíba. CARTA dos oficiais da Câmara da Paraíba, ao rei [D. João V], sobre a péssima notícia da Paraíba ficar subordinada à capitania de Pernambuco e as implicações que poderão advir. AHU_CU_014, Cx. 13, D. 1084.

${ }^{31}$ Expressões como "nação" e "pátria", no mundo português da Época moderna, possuíam sentidos completamente distintos daqueles atualmente empregados. Segundo Hespanha, tais léxicos remetiam a "um laço natural de pertença a um território ou a uma comunidade, marcados pelo nascimento, máxime por um nascimento de pais também eles nascidos na terra (...)". Elas também carregavam consigo a ideia de amor ao lugar de nascimento, um sentimento natural no Antigo Regime, “(...) o amor da comunidade e da pátria -, entendido ainda o termo como 'lugar de nascimento' ('la pátria-chica, a 'terra natural', de onde decorrem os conceitos de 'senhor natural' e de 'súdito natural'”. HESPANHA, António Manuel. Pequenas repúblicas, grandes Estados. Problemas de organização política entre Antigo Regime e Liberalismo. In: JANCSÓ, István (org.). Brasil: formação do Estado e da Nação. São Paulo: Hucitec; Ed. Unijuí; Fapesp, 2003, p. 96. Cf. tb. HESPANHA, António M.; SILVA, Ana Cristina Nogueira da. A identidade portuguesa. In: HESPANHA, António M. (coord.). História de Portugal. O Antigo Regime, 1620-1807). Vol. IV. Lisboa: Círculo de Leitores, 1993, p. 18-37. Por outro lado, e embora Herzog trate especificamente dos mundos hispano e hispano-americano, sua reflexão sobre os conceitos de "naturalidade" e "vizinhança" e sua crítica à aplicação anacrônica de qualquer ideia de "nacionalidade" que exceda a identificação com as comunidades locais da época moderna, também são muito úteis aos estudos análogos do caso português para as identidades locais e suas 356 SÆCULUM - ReVISTA DE HistóRIA [39]; João Pessoa, jul./dez. 2018.
} 
de cultura política gestada há 73 anos: que a capitania da Paraíba nunca foi de donatário; que a sua única cidade e cabeça do governo, por sua antiguidade e status de "cidade real", tinha superioridade à Olinda; que todas as capitanias do Estado do Brasil estavam sujeitas ao Governo Geral; e que a manutenção da independência da régia capitania da Paraíba seria imprescindível para pôr freios às recorrentes agitações de Pernambuco.

A esse respeito, dois aspectos merecem destaque, pois constituem o cerne dessa produção identitária sobre o espaço na velha e régia capitania quinhentista. Em primeiro lugar, no tocante à rede urbana e ao papel proeminente das cidades reais na hierarquização do poder e da política no Brasil colonial sob o Antigo Regime, Beatriz Piccolotto Siqueira Bueno, ao tratar do caso da capitania de São Paulo, afirmou que

(...) as instâncias de poder organizavam-se hierarquicamente em instituições irradiadas a partir das "cidades reais". Seguindo padrões portugueses, as instâncias administrativa, jurídica e eclesiástica sobrepunham seus territórios no espaço. As vilas tinham papel hierarquicamente inferior às "cidades", mas superior às capelas $e$ freguesias. Todas, igualmente, eram tentáculos metropolitanos na distante "Conquista", cumprindo papéis distintos na lógica da rede urbana. ${ }^{32}$

Entretanto, ainda que a hierarquia urbana entre cidades e vilas seja válida como padrão geral da urbanização no Império português, como apontou Bueno, é preciso considerar que a materialidade da colonização nas capitanias do Norte permitiu a existência peculiar de cidades reais "desprestigiadas", como a da Paraíba de Nossa Senhora das Neves e a de Natal, que, fundadas entre o final do século XVI e início dos Seiscentos e desempenhando papéis protagonistas na conquista e ocupação dos territórios indígenas ao norte de Itamaracá, caíram progressivamente em flagrante atraso políticoadministrativo e econômico dada a proximidade com Olinda e Recife. ${ }^{33}$ Esta última, sobretudo com a invasão holandesa, constituiu-se em praça mercantil privilegiada para os negócios do açúcar e dos escravos africanos e, depois, do gado e de seus derivados, capitalizando sua projeção política e um hinterland que se estendia de Penedo ao Ceará. ${ }^{34}$ Ademais, o demérito da urbe da Paraíba não implicou na desistência, por parte de suas elites camarárias, caso que nos interessa aqui, em defenderem os espaços de poder que consideravam-lhes próprios em função da precedência na conquista da terra e na posição superior na simbólica hierarquia urbana do Império. ${ }^{35}$

Em segundo lugar, defendendo seu quinhão e utilidade no conjunto da Monarquia, os vereadores da Paraíba recordaram ao rei terem recebido a Sua graça ao reconhecê-los como honrados e fiéis vassalos pelo serviço prestado quando da sublevação da capitania vizinha, em 1710; explicaram ainda que tão grande feito só fora possível por serem eles isentos da jurisdição de Pernambuco à época pois, caso contrário, poderiam ter botado tudo a perder por estarem sujeitos a ela. ${ }^{36}$ Aquilo que havia sido vaticinado por Mathias de Albuquerque Maranhão em 1661, de que os inimigos também estariam a partir daquele momento no interior do Estado do Brasil, foi concretizado com a Guerra dos Mascates de 1710-11. Este fato se revelará para os camarários, como contrapartida, num profundo sentimento

culturas políticas, como a analisada neste artigo. A esse respeito, cf. HERZOG, Tamar. Defining Nations: immigrants and citizens in Early Modern Spain and Spanish America. New Haven: Yale University Press, 2003. Para uma leitura comparada com o mundo colonial inglês, cf. GREENE, Jack. Peripheries and center: constitucional development in the extended polities of the British Empire and the United States, 1607-1788. An Arbor: University of Michigan Library, 1990; e também GREENE, Jack. Negotiated authorities. Essays in colonial political and constitucional history. Charlottesville: University of Virginia Press, 1994.

${ }^{32}$ BUENO, Beatriz P. S. Dilatação dos confins: caminhos, vilas e cidades na formação da Capitania de São Paulo (15321822). Anais do Museu Paulista, São Paulo, v.17., n.2., p. 251-294. jul.- dez. 2009, p. 252.

${ }^{33}$ Entre 1655 e 1709, portanto após perder o estatuto de cidade-capital conferido durante a dominação neerlandesa, institucionalmente o Recife foi nada mais que uma freguesia de Olinda. A partir de 1709 ascendeu à condição de vila, no que permaneceu até 1824, quando foi feita cidade e, três anos depois, recobrou a condição de capital, já durante o Império. Cf. SOUZA, Tratos e Mofatras..., p. 54.

${ }^{34}$ MELLO, Evaldo Cabral de. A ferida de Narciso. Ensaio de história regional. São Paulo: Editora SENAC São Paulo, 2001, p. 53ss; também DIAS, Monopólio Indireto...

${ }^{35}$ Sobre a experiência política e jurisdicional nas capitanias do Norte e os conflitos locais em função da hierarquia urbana no mundo português, cf. CHAVES JR., As capitanias de Pernambuco... Para uma história da urbanização na cidade da Paraíba, cf. MOURA FILHA, Maria Berthilde. De Filipéia à Paraíba: uma cidade na estratégia de colonização do Brasil. Séculos XVIXVIII. João Pessoa: IPHAN - Superintendência na Paraíba, 2010.

${ }^{36}$ AHU ALC CU 014, Cx. 13, D. 1084. 
de traição que lhes imputarão a nobreza pernambucana; um rancor que só se aplacaria com a subordinação e o esquecimento.

\section{6}

O final do mês de fevereiro coincidiu com a chegada das correspondências que o correio marítimo levara à vila do Recife, e entre as cartas régias remetidas à capitania da Paraíba e endereçadas ao governador Luís Antônio Lemos de Brito, uma delas desfechava um duro golpe sobre a sua população. Dizia o rei que, atendendo a uma avaliação do Conselho Ultramarino, por não possuir a capitania da Paraíba receita suficiente para assegurar um governo independente, ficasse ela sujeita à capitania de Pernambuco. Para tanto, esclarecia que ao findar o triênio do governador em exercício, fosse ele substituído por um capitão-mor com o mesmo soldo que se pagava na capitania do Rio Grande do Norte.

Ora, o cenário econômico não era nada alvissareiro. Os desafios enfrentados pelos produtores de açúcar do litoral da Paraíba, a amargarem uma crise já secular no setor, reclamavam à Coroa saídas emergenciais para mitigar os efeitos nefastos das secas e falta de condições para a aquisição da mão de obra escravizada. Ao longo das décadas de 1740 e 1750, alguns governadores e provedores da Paraíba propuseram uma engenharia fiscal inovadora, como a cobrança da passagem dos gados pelo sertão da Paraíba e que iam em direção às Minas, ou mesmo o aumento da área produtiva da capitania, anexando as várzeas de Goiana. ${ }^{37}$ Tais meios serviriam para salvaguardar as despesas que se faziam para manter os imprecisos pagamentos dos "filhos da folha" e com os diversos serviços de empreiteiros e mestres de ofícios.

Até então, o que se praticava para compensar os déficits correntes da receita da capitania era fazer a contratação da dízima das alfândegas de Pernambuco e Paraíba em um só contrato, ou seja, estabelecendo que a arrecadação do imposto de $10 \%$ sobre a importação de mercadorias fosse feita conjuntamente. A ideia, instituída no ano de 1723, obrigava a Provedoria de Pernambuco a repassar vinte mil cruzados anuais e procurou dar solução ao antigo problema, já levantado desde o século XVII, como vimos, de que se não estivessem os portos tão próximos não padeceria a Paraíba das faltas de recursos em virtude do extravio de suas produções e pagamentos. ${ }^{38}$

Tal arranjo, contudo, mostrou-se capenga. Segundo o provedor de Pernambuco, por não terem as frotas a exatidão pretendida, seria impossível repassar regularmente o envio integral do que se devia. ${ }^{39}$ Porém, isso não importava para a Provedoria da Paraíba, pois suas despesas anuais não podiam ficar ao sabor da conjuntura econômica europeia para fazerem os navios seguirem o destino da América. A ideia de que era proximidade com o porto do Recife a causa do malogro fiscal da Paraíba remontava à Ambrósio Fernandes Brandão, cristão-novo, mercador e senhor de engenho na Paraíba antes da dominação holandesa, mas fora recuperada dessa feita para explicar a ganância com que Pernambuco ambicionava as suas rendas, e os camarários, mais uma vez, foram mestres na arte de conferir usos políticos ao passado, adensando a cultura política local erguida para demarcar sua autonomia perante a poderosa capitania vizinha. ${ }^{40}$

A carta-resposta da câmara à ordem régia de anexação, além de tornar a repetir que a capitania da Paraíba nunca foi de donatário, que a cidade da Paraíba, pela antiguidade, tinha superioridade à Olinda e que todas as capitanias do Estado do Brasil estavam sujeitas apenas ao Governo Geral, trazia outros ingredientes. Desta vez, os argumentos mostrar-se-iam também como uma síntese e ponto de chegada de uma narrativa histórica que vicejou um curioso e insipiente sentimento nativista na cidade

\footnotetext{
${ }^{37}$ CHAVES JR., As capitanias de Pernambuco..., p. 216-17.

${ }^{38}$ MENEZES, Colonialismo em ação...

${ }^{39}$ MENEZES, Colonialismo em ação... Cf. também MENEZES, Mozart Vergetti. Sonhar o céu, padecer no inferno: governo e sociedade na Paraíba do século XVIII. In: BICALHO, Maria Fernanda \& FERLINI, Verá Lúcia Amaral (org.). Modos de governar: ideias e práticas políticas no Império Português. Séculos XVI a XIX. São Paulo: Alameda, 2005, p. 330.

${ }^{40}$ Como ficará claro mais à frente, os olhares exógenos de Brandão, um homem do Atlântico e pouco articulado às engenharias relacionais das capitanias do Norte do ante-bellum, não eram os mesmos daqueles senhores de engenho seus contemporâneos e cujos laços de parentesco estavam todos estabelecidos ao sul de Goiana, nas capitanias de Itamaracá e Pernambuco, para onde sempre se dirigiam quando careciam dalgum suprimento. O uso político do relato de Brandão por setores das elites locais da Paraíba e, sobretudo, pelos capitães-mores governadores dessa capitania, só fará pleno sentido após a Guerra da Liberdade Divina, quando a discórdia "rachará" definitivamente a açurocracia pernambucana. 
da Paraíba cujo fundamento era uma cultura política que, após a Guerra da Liberdade Divina, progressivamente se desgarrou do "berço pernambucano" e passou a nele identificar o principal rival o inimigo interno do qual falara Mathias de Albuquerque Maranhão em 1661.

Reconstruindo o passado, não sem muitas contradições, como de costume nesse tipo de produção narrativa, os camarários foram ao encontro de uma história que desconectasse as origens da capitania da Paraíba daquelas intrínsecas ligações com a elite olindense. Para tanto, copiaram sugestivas passagens da História da América Portuguesa, de Rocha Pita, e alinharam a doação da capitania da Paraíba a João de Barros, no longínquo ano de 1535, omitindo as tardias expedições de conquista, principalmente de Diogo Flores de Valdez.

Foi sempre o governo desta Capitania da Paraíba independente, porque dividindo os senhores reis predecessores de vossa majestade o Brasil em quatorze capitanias, que tiveram donatários, ficou livre a Paraíba até desta sujeição; pois havendo o Sr. Rei D. João, o $3^{\circ}$, feito doação dela ao famoso historiador João de Barros, que o mandou povoar por dois filhos com grandes despesas de gentes e naus, se perderam quase todos no Maranhão aonde os levou as correntes das águas, e depois o mandou povoar o senhor Cardeal Rei por Frutuoso Barbosa por conta da Coroa em que sempre se conservou sem outra sujeição que a mesma que tem a Capitania de Pernambuco [à Bahia], apesar das repetidas diligências dos seus moradores para que esta capitania fosse dependência daquele governo. ${ }^{41}$

Dito isto, os camarários também fizeram questão em demarcar que os naturais da Paraíba não eram pernambucanos! Negação auto-referencial, afinal, alfinetavam os vizinhos que sempre desmereceram as graças da sua alteza real por lhes sobrarem a ira e o ódio como ocorreu na Guerra dos Mascates. E foi pela participação neste episódio, exatamente por conterem os nefastos instintos da nobreza pernambucana, que os oficiais do Senado da câmara denunciaram os riscos de ficarem subordinados aos que nunca os perdoaram.

Depois deste tempo ficaram os pernambucanos conservando entranhável rancor aos naturais da Paraíba; e [o] que farão [eles] agora vendo sujeitos os mesmos que brasonavão de fieis? Sendo crime que recordam a mesma jactância da nossa fidelidade a qual eles não tiveram por cuja causa foram castigados, a vista do que justo é o temor que nos move a pretender da real piedade de vossa majestade de quem nunca desmerecemos a graça de nos ouvir, queira deferir ao nosso requerimento, ordenando que a pessoa que nos governar fique independente de Pernambuco, como tem sido todos os capitães mores desta capitania. ${ }^{42}$

Para os naturais da Paraíba, viver na subordinação estimularia não só o apetite voraz dos pernambucanos sobre as suas rendas, "em virtude da arrematação de ambas as alfândegas em um só contrato", mas também o temor de levarem agora, diziam, "as nossas isenções, as nossas rendas as nossas regalias", um receio bem típico das identidades das "pátrias-chicas" no Antigo Regime ibérico, sempre preocupadas em manter os espaços próprios e os direitos comuns adquiridos. ${ }^{43}$ Além disso, o escopo do temor da anexação ganhava contornos precisos ao tornar evidente que o passado de engrandecimento, fruto da devoção e fidelidade à Sua Majestade, não se conciliaria com o futuro anunciado por aquela mudança no status da capitania, quando a anexação os impossibilitaria de serem governados por pessoas de maior graduação e dignidade correspondentes:

(...) se a origem desta Real determinação de Vossa Majestade é para se diminuir o ordenado dos 4 mil cruzados que tem presente os governadores, ainda parece que diminuindo-se e conservando-se isenta a capitania de outro domínio, haverão opositores de maior graduação, o que não sucederá talvez ficando sujeita. ${ }^{44}$

\footnotetext{
${ }^{41}$ AHU_ACL_CU_014, Cx. 19, D. 1495, grifos nossos.

${ }^{42}$ AHU_ACL_CU_014, Cx. 19, D. 1495, grifos nossos.

${ }^{43}$ AHU_ACL_CU_014, Cx. 19, D. 1495. Cf. nota 29.

${ }^{44}$ AHU ACLCU-014, Cx. 19, D. 1495.
} 
Esta contestação da câmara abriu uma divergência entre o Conselho Ultramarino e os procuradores da Fazenda e da Coroa. Se, para o procurador da Fazenda, os oficiais da Paraíba tinham razão e o corte no ordenado do governador em nada melhoraria a receita da capitania, o procurador da Coroa acrescentava que "diante das supostas circunstâncias em que se achavam os moradores da Paraíba com os de Pernambuco, seria conveniente conservá-los na separação dos governos". Mostrando-se hesitante, o Conselho Ultramarino resolveu solicitar ao vice-rei do Brasil que emitisse um parecer questionando o governador de Pernambuco e a câmara, nobreza, povo e o governo da Paraíba sobre os prejuízos que poderiam ter com a anexação, e se o rendimento da Fazenda Real da capitania da Paraíba poderia sustentá-la separada e sem a ajuda de Pernambuco. ${ }^{45}$

Mesmo que não se tenha conhecimento do andamento do parecer do vice-rei, o assunto veio à baila na escolha do novo capitão-mor da Paraíba, em novembro de $1756 .{ }^{46}$ Naquele momento, os conselheiros foram enfáticos dizendo serem insuficientes as contestações da câmara e, seguindo a ordem de anexação, encaminharam os nomes dos opositores para a consulta real. O despacho, contudo, só seria conhecido um ano depois, em setembro de 1757. Nele, D. José I escolheu para a Paraíba um capitão-mor que não constava entre os postulantes, Francisco Xavier de Miranda Henriques. $^{47}$

Quando fora escolhido para a Paraíba, Miranda Henriques, que era fidalgo da Casa Real, já acumulava doze anos como capitão-mor do Rio Grande do Norte (1742-1754) e três no Ceará (17551758), duas capitanias com longo histórico de subordinação à Pernambuco. ${ }^{48}$ Tal escolha pode ter sido usada pelo Conselho Ultramarino como estratégia para "pacificar" a inflamada política na Paraíba, que passava a ter um capitão-mor "familiarizado" com o estatuto de sujeição militar. No entanto, em vez de seguir como planejado, Henriques rumou para a vila do Aracati, onde ficou até tomar posse na Paraíba, em 1761. ${ }^{49}$ Nesse interregno, José Henrique de Carvalho, capitão de infantaria da vila de Olinda, foi nomeado sem alardes pelo então governador general de Pernambuco, Luiz Diogo Lobo da Silva, para a Paraíba. ${ }^{50}$ Tal desfecho, com a nomeação de capitães-mores alijados em sua autoridade e com testada obediência à Pernambuco, não poderia conduzir a outra conclusão senão a irreversibilidade da anexação.

Cabe, contudo, advertir que, embora o contexto de meados do século XVIII tenha ficado conhecido em função das chamadas "reformas pombalinas", a solução adotada para a arrastada ruína fiscal da Paraíba não era nova, muito menos "reformista". Subordinar capitanias menos destacadas economicamente às de maior importância, ainda mais em momentos de crise, conferindo a estas a dignidade de "capitanias de primeira grandeza", "capitanias gerais" ou "capitanias principais", com o patente de governador e capitão-general ao seu mandatário, era um expediente corriqueiramente usado pela Coroa e estava em plena consonância com os modos de governar do Antigo Regime. ${ }^{51}$ Neste caso, se quisermos compreender adequadamente os efeitos da subordinação da Paraíba, será preciso percebê-los através da interação entre as experiências (às vezes traumáticas) da política local e as expectativas acerca da aplicação, sempre adaptável às diferentes realidades e cheias de marchas $e$ contramarchas, do reformismo ilustrado. ${ }^{52}$

\footnotetext{
${ }^{45}$ AHU ACL CU 014, Cx. 19, D. 1495.

${ }^{46}$ AHU ACLCU-014, Cx. 19, D. 1508.

${ }^{47}$ AHU_ACL_CU_014, Cx. 19, D. 1508.

${ }^{48}$ Cf. Papéis de serviço de Francisco Xavier de Miranda Henriques. Cf. AHU ACL CU 006, Cx. 6, D. 390; e AHU_ACL_CU_006, Cx. 19, D. 392. O Ceará havia sido sujeito à Pernambuco desde a restauração luso-brasileira contra os neerlandeses; já o Rio Grande perdera a autonomia governativa em 1701, no decorrer da chamada Guerra dos Bárbaros. A esse respeito, cf. CHAVES JR. As capitanias de Pernambuco..., p. 285.

${ }^{49}$ Requerimento do capitão-mor da Vila do Aracati no Ceará, Francisco Xavier de Miranda Henriques, ao rei, D. José I, acerca de 14 de dezembro de 1759, pedindo para se tirar devassa e se punirem os culpados do rapto de suas filhas em Goiana. Cf. AHU_ACL_CU_015, Cx. 19, D. 7368.

${ }^{50}$ AHU_ACL_CU_014, Cx. 19, D. 1545.

${ }^{51}$ Cf. ARAÚJO, Renata Malcher de. Configurações internas: as fronteiras entre as capitanias. Promontoria - Revista de História, Arqueologia e Património da Universidade do Algarve, ano 11, n.11, 2014; ver também MONTEIRO, Nuno Gonçalo. Governadores e capitães-mores do Império Atlântico português no século XVIII. In: BICALHO \& FERLINI, Modos de governar...; BELLOTTO, Heloísa Liberalli. Autoridade e conflito no Brasil colonial: o governo do Morgado de Mateus em São Paulo (1765-1775). 2 ed. São Paulo: Alameda, 2007.

${ }^{52}$ Para uma interpretação atual e mais equilibrada do reformismo de D. José I e de seu mais influente secretário, Sebastião de Carvalho e Mello, não afeita aos estereótipos de historiografias anteriores, cf. MONTEIRO, Nuno Gonçalo Pimenta. As reformas na monarquia pluricontinental portuguesa: de Pombal a dom Rodrigo de Sousa Coutinho. In: FRAGOSO, João \& 360 SÆCUlUM - REvista DE HistóRIa [39]; João Pessoa, jul./dez. 2018.
} 
Consciente de que a anexação per se não resolveria todos os impasses, a Coroa ocupou-se em fechar algumas arestas recalcitrantes na tarefa de promover a centralidade de Pernambuco nas capitanias do Norte, vista como a melhor estratégia para a recuperação da economia regional, mister que reservara conspícuo interesse naqueles meados de centúria. Uma primeira medida fora a criação da Companhia Geral de Pernambuco e Paraíba, em 1759, que fortaleceu as sólidas rotas comerciais do açúcar nas principais várzeas do litoral, estimulando também outros pontos de contato, como a indústria do gado e do couro nos portos dos sertões do Rio Grande do Norte e do Ceará. Tudo isso contribuiu para dinamizar circuitos mercantis comandados pelos negociantes lusos do Recife com suas cadeias monopolizadas de crédito e financiamento. ${ }^{53}$

Em segundo lugar, com a carta régia de 22 de março de 1766, que passou aos generaisgovernadores de Pernambuco a prerrogativa exclusiva de propor, nas suas capitanias anexas, as patentes das tropas de ordenanças e auxiliares, desbaratou-se não apenas a autonomia militar do capitão-mor da Paraíba, mas sobretudo alijou-lhe de qualquer capacidade para compor alianças com bandos de localidades distantes da cabeça da capitania, como a ribeira do Mamanguape, ao norte, $e$ os sertões para além da Serra da Borborema, a oeste. Tais potentados passaram a orbitar quase exclusivamente em torno do general na busca por sua chancela no exercício do mando local (através da concessão de patentes militares e terras, por exemplo). ${ }^{54}$ Sobre este ponto, apoiado nas conclusões de Cristiane Pagano de Mello, Bruno Cezar Santos da Silva, em estudo recente, esclareceu que

(...) a segunda metade do século XVIII foi marcada por intenso processo de militarização da sociedade colonial, onde possuir uma patente militar, especialmente das tropas auxiliares e de ordenanças, se tornava um indiscutível dispositivo de nobilitação e de consolidação das elites da terra, chegando, inclusive, a agregar maior atração que os cargos de vereança que, até então, eram mais visados. ${ }^{55}$

De resto, o movimento "Pró-Pernambuco" do reinado de D. José promoveu arrojados projetos de reforma territorial que endossaram a capitalidade recifense em diferentes áreas. Com grande capacidade de observação das experiências locais, tal movimento enfeixou no general-governador um extraordinário capital simbólico que, garantindo-lhe credibilidade e respeito junto aos homens-bons de municipalidades recém-criadas, abrira espaços para complexos arranjos políticos, às vezes não tão fincados no figurino da legalidade. Exemplo disso foram as intrínsecas relações do capitão-mor da vila de Pombal (alto do sertão da Paraíba), Francisco de Arruda Câmara, com os governadores de Pernambuco.$^{56}$ Criada em 1772 , a vila de Pombal e seu principal potentado já nascera numa relação umbilical com a vizinha capitania, mantendo posição sempre refratária perante quaisquer investidas de poder dos capitães-mores que residiam na cidade da Paraíba, não reputando-os nem por

\section{GOUVEA,}

(org.) Nas tramas das redes...; cf. ainda MONTEIRO, Nuno G. P.. D. José I na sombra de Pombal. Lisboa: Círculo de Leitores/Centro de Estudos dos Povos e Culturas de Expressão Portuguesa, 2006.

${ }^{53}$ Sobre a Companhia Geral de Pernambuco e Paraíba, cf. o estudo de ARAÚJO, Clara Maria Farias de. O trato dos homens de negócio de Pernambuco: metamorfoses nas hierarquias (1730-1780). Tese (Doutorado em História Social), Universidade Federal do Rio de Janeiro, Rio de Janeiro, 2012. Sobre a integração comercial nas capitanias do Norte dos Setecentos, cf. ainda CHAVES JR., José Inaldo. Por ser Pernambuco tão chegado: anexação, governos e mercados ultramarinos na Capitania da Paraíba (1791-1799). Almanack, v.8, p. 120-141, 2014; ROLIM, Leonardo Cândido. "Tempo das carnes" no Siará Grande: dinâmica social, produção e comércio de carnes secas na vila de Santa Cruz do Aracati (c.1690-c.1802). Dissertação (Mestrado em História), Universidade Federal da Paraîba, João Pessoa, 2012; e MEDEIROS, Tiago Silva. "O sertão vai para o Além-Mar": a relação centro e periferia e as fábricas de couro em Pernambuco nos setecentos. Dissertação (Mestrado em História), Universidade Federal do Rio Grande do Norte, Natal, 2009.

${ }^{54}$ CHAVES JR., As duras cadeias de hum governo subordinado..., sobretudo o terceiro capítulo.

${ }^{55}$ SILVA, Bruno Cezar Santos da. Entre defesa e ordem: os corpos militares da Paraíba na trama da subordinação à capitania de Pernambuco (1755-1799). Dissertação (Mestrado em História), Universidade Federal da Paraîba, João Pessoa, 2013; cf. ainda MELLO, Cristiane Figueiredo Pagano de. A centralização política e os poderes locais ultramarinos: as câmaras municipais e os corpos militares. Revista História Social, Campinas-SP, 2005, n.11. p. 153-172.

${ }^{56}$ Sobre o potentado local Francisco de Arruda Câmara, cf. o estudo recente de PAIVA, Yamê Galdino de. Vivendo à sombra das leis: António Soares Brederode entre a justiça e a criminalidade. Capitania da Paraíba (1787-1802). Dissertação (Mestrado em História), Universidade Federal da Paraíba, João Pessoa, 2012. Sobre as dinâmicas políticas do sertão da Paraíba e suas tramas envolvendo o general de Pernambuco no século XVIII, cf. também GUEDES, Paulo Henrique Marques de Queiroz. "No íntimo do sertão": poder político, cultura e transgressão na capitania da Paraíba (1750-1800). Tese (Doutorado em História), Universidade Federal de Pernambuco, Recife, 2013. 
governadores da capitania naqueles longínquos sertões. ${ }^{57}$

Na verdade, desde a década de 1760, após presenciar a subordinação em 1756, os edis da cidade da Paraíba tiveram que amargar a perda do confortável lugar de única municipalidade da capitania. Isto ocorreu porque, junto com as demais medidas já apontadas para aquele meados da centúria, uma redefinição da malha urbana da Paraíba a partir da gestão do general Luiz Diogo Lobo da Silva (175963), que aplicou o Diretório dos Índios em Pernambuco e suas anexas, fragmentou irreversivelmente o termo da cidade quinhentista, obrigando a sua câmara a repartir os recursos políticos e econômicos com as novas vilas erigidas. ${ }^{58}$ Por essa época, a câmara perdera quase tudo que lhe restava das já minguadas glórias de cidade real e cabeça do governo da capitania.

Em carta escrita em 28 de julho de 1766, os vereadores da Paraíba de Nossa Senhora das Neves, apesar de reconhecerem o pio e reverente mandato de Sua Majestade para "republicar os Indios, que té então vivião aldeados no experso sertão desta Capitania, sem aquelle regimen de vassalos (...)", muito lamentaram que a execução da Real Ordem teria causado enorme prejuízo a esta "sempre leal cidade da Paraíba", posto que "o excessivo termo" das novas vilas teria sido erguido penalizando a cidade, que ficara "(...) com limitado de nove legoas (...)", arcando a câmara com uma danosa perda em sua arrecadação e os oficiais de justiça com a redução de seus donativos. ${ }^{59}$

Esta patente verdade se faz mui compassiva da Real atenção, para onde apelamos em nome desta Cidade, já que no regimento daquellas villas se não faz participante a este Senado da mente Soberana para ficar intendido do referido termo, tão pouco a esta jurisdição, do que esperamos de tão pia, catholica e Real Protecção se digne terminar a cada uma daquelas vilas, o território de seis legoas, na inteligência do practicado com aquella vila de Sam Joze do Ryo Negro, ficando esta Cidade logrando o mais, que de antes tinha, por que tão bem redunda em aumento da Real Fazenda, no donativo dos ofícios de justiça, e alguns contratos, em que ouve bastante diminuição, com a que teve este território. ${ }^{0}$

Com a chegada do último terço de século, a câmara da cidade da Paraíba, perdida a guerra contra a capitalidade do Recife, recolhera-se aos assuntos mais ordinários. O flanco da batalha contra as investidas de Pernambuco e de seus generais e em favor da recuperação da autonomia da capitania se concentraria agora na figura de um enfraquecido capitão-mor. As constantes denúncias e reclamações enviadas ao Conselho Ultramarino durante a balzaquiana gestão do governador da Paraíba Jerônimo José Mello e Castro (1764-97), espelharam a experiência de comandar uma capitania sujeita a outrem, laços com o passado, sem força no presente, sem história. A anexação só seria revertida com uma nova onda de reformismo no mundo português, ainda mais incisiva e homogeneizadora que aquela de D. José I, posto que refletira a lenta, mas constante, decadência das culturas políticas do Antigo Regime e de sua estrutura jurídico-política corporativa, ainda muito resistentes à época de Sebastião de Carvalho e Mello. No final dos Setecentos, avançaram com força nunca vista as novas formas de ver e conceber a organização da Monarquia e a sua relação com as comunidades.

Sob o reinado de D. Maria I, os vínculos fortes das comunidades locais, com suas noções de naturalidade e pertencimento baseadas na conquista da terra à custa de sangue e fazendas e nos monopólios e privilégios dela decorrentes, foram sendo submetidas pela emergência de um novo conceito de "pátria" que expressava uma comunidade política muito mais ampla e, dir-se-á, artificial,

\footnotetext{
${ }^{57}$ CHAVES JR., As capitanias de Pernambuco..., p. 292.

${ }^{58}$ Até o final dos Setecentos, as novas vilas da Paraíba somariam nove, além da Paraíba de Nossa Senhora das Neves, que permaneceu como única cidade. Foram erigidas a vila de Monte-mor (1762), a vila de São Miguel da Baía da Traição (1762), a vila de Nossa Senhora do Pilar (1763), a vila do Conde (1764-5) e a vila de Alhandra (1765), completando o circuito de criações na zona da mata paraibana. Apenas na década de 1770 foram feitas ereções para além da serra da Borborema, nos sertões da capitania, elevando à categoria de vilas antigos lugares, povoações e julgados. Foram criadas as vilas de Pombal, 1772; vila Nova da Rainha (atual Campina Grande), em 1790; vila Real de São João (Cariri Velho) e vila Nova de Souza (1800). A esse respeito, cf. SOARES, Maria Simone Morais. Formação da Rede Urbana do Sertão de Piranhas e Piancó na Capitania da Paraíba Setecentista. Dissertação (Mestrado em Arquitetura e Urbanismo), Universidade Federal da Paraíba, João Pessoa, 2012.

${ }^{59}$ AHU ACL CU 014, Cx. 23, D. 1800, grifos nossos.

${ }^{60}$ AHU_ACL_CU_014, Cx. 23, D. 1800.
} 
que encontrou no Estado a sua principal expressão e elemento agregador. ${ }^{61}$ Como advertiu José Subtil, com a ilustração de fin de siècle, influenciada pelas ideias liberais, a Coroa consideraria cada vez mais "o governo de todos e menos o governo de cada um".$^{62}$ É possível que os vereadores da cidade da Paraíba, após derrotas amargas, finalmente tenham sentido a mudança dos tempos.

\section{9}

Em 1797 falecera o capitão-mor Jerónimo José de Mello e Castro, após realizar o mais longo e solitário governo que se tinha notícia na Paraíba colonial. Por três décadas - 2/3 do período total de anexação a Pernambuco - Mello e Castro enfrentou conflitos de jurisdição com diferentes oficiais da administração, atritos renhidos com os generais de Pernambuco e até uma tentativa de assassinato orquestrada por setores das elites locais. Apesar dos recorrentes e lamuriosos pedidos para que Lisboa livrasse-o da subordinação ou mesmo retirasse-o para uma capitania independente (ou principal), correspondente a sua dignidade e em retribuição por décadas de serviço à Sua Majestade, o capitãomor fora abandonado até a sua morte. Naquela época, o estado de subordinação da Paraíba e a condição periférica de sua cidade nos acertos regional e imperial confundiram-se com o desencanto de Mello e Castro, que ficara isolado na velha urbe sem qualquer capacidade decisória. ${ }^{63}$

Em seu lugar tomou posse Fernando Delgado Freire de Castilho, um quadro da Monarquia afinadíssimo com os princípios daquela "geração de 1790", que tinha por modelo a ilustração economicamente liberal e fisiocrática de dom Rodrigo de Souza Coutinho. ${ }^{64} \mathrm{~A}$ conjuntura também era distinta daquela dos idos de 1750 . Tudo mudara rapidamente e, agora, a própria política de anexação das capitanias do Norte passara a ser questionada depois de apresentar duvidosos resultados. ${ }^{65}$

No regimento dado a Freire de Castilho, assinado por dom Rodrigo, constava inúmeras recomendações e cobrava-se informações detalhadas sobre a defesa da capitania, as condições das fortificações e corpos militares, até o seu estágio econômico, suas produções, matas, comércio e população. Além do interesse geracional em efetivamente conhecer e explorar racionalmente as riquezas das possessões ultramarinas, sentimento típico da política imperial no reinado de D. Maria I, no escopo desse inventário acerca da Paraíba também estava a prima intenção de verificar a conveniência de mantê-la subordinada a Pernambuco ou, enfim, fazê-la novamente independente aliás, como sempre tivera sido desde a sua fundação, assim entoava o coro das vereações da cidade e, mais recentemente, do capitão-mor falecido. ${ }^{66}$

As orientações do conde de Linhares também interrompiam um silêncio de quatro décadas, desde quando, em 1755, o Conselho Ultramarino indagou o então capitão-mor Luiz António Lemos de Brito

\footnotetext{
${ }^{61}$ HESPANHA, Pequenas repúblicas, grandes Estados, op. cit., p. 102 passim. Para uma discussão mais ampla sobre o assunto, cf. ANDERSON, Benedict. Comunidades imaginadas: reflexões sobre a origem e a difusão do nacionalismo. Trad. Denise Bottman. São Paulo: Companhia das Letras, 2008.

${ }^{62}$ SUBTIL, José, O Governo da Fazenda e das Finanças (1750-1974). In: CRUZ, Mário Pinho da (ed.). Dos Secretários de Estado dos Negócios da Fazenda aos Ministros das Finanças (1788-2006). Lisboa: Secretaria-Geral do Ministério das Finanças e da Administração Pública, 2006, p. 36-69.

${ }^{63}$ Acerca da passagem de Jerónimo José de Melo e Castro pela Paraíba, cf. CHAVES JR., As duras cadeias de hum governo subordinado..., sobretudo o capítulo 3.

${ }^{64}$ Sobre a geração de 1790, cf. MAXWELL, Kenneth. A devassa da devassa: a Inconfidência Mineira, Brasil - Portugal, $1750-$ 1808. Rio de Janeiro: Paz e Terra, 1985; e SILVA, Andrée Mansuy-Diniz. Portrait d'un Homme d'État: D. Rodrigo de Souza Coutinho, Comte de Linhares, 1755-1812. Paris: Centre Culturel Calouste Gulbenkian, 2002.

${ }^{65}$ Não custa lembrar que, embora o momento mais lembrado da política de capitanias anexas no Norte do Estado do Brasil seja, pois, a sujeição da Paraíba, em 1756, tal experiência governativa possuía um longo histórico na região, tendo sido subordinado a Pernambuco o Rio Grande em 1701 e, antes disso, o Ceará, por volta de 1656, logo depois da "debacle" neerlandesa. Após a Paraíba, Itamaracá, transcorrida verdadeira batalha judicial entre a Coroa e os donatários e seus herdeiros, seria definitivamente incorporada a Pernambuco, perdendo inclusive o estatuto de capitania, o que não ocorrera com as demais. Sobre a incorporação de Itamaracá, cf. VELEZ, Luciana de Carvalho Barbalho. Donatários e administração colonial: a Capitania de Itamaracá e a casa de Cascais (1692-1763). Tese (Doutorado em História), Universidade Federal Fluminense, Niterói, 2016.

${ }^{66}$ In: PINTO, Irineu Ferreira. Datas e notas para a História da Paraíba. Edição Fac-similar. João Pessoa: Editora Universitária, 1977, vol. I, p. 80. Os deveres investidos à Fernando Delgado Freire de Castilho foram, inclusive, muito recomendados em sua atenção ao próprio general de Pernambuco, à época dom Tomás José de Melo, que recebera instruções do secretário de Estado da Marinha e Ultramar para que auxiliasse o governador da Paraíba naquilo tudo que preciso fosse para atingir o mister. Cf. AHU_ACL_CU_015, Cx. 198, D. 13704 (1798, fevereiro, 14, Recife); AHU_ACL_CU_015, Cx. 198, D. 13717 (1798, fevereiro, 22, Recife).
} 
(1754-1757) acerca das condições de manter um governo autônomo na Paraíba. Lemos de Brito denunciou a deficiência das rendas provocada pelo atraso no envio dos vinte mil cruzados da dízima por parte da Provedoria de Pernambuco e isso foi determinante para a conhecida decisão da Coroa. Em 1797, o questionamento era inverso, pois, ainda que o cenário, com a recuperação relativa da economia do açúcar e a diversificação agrícola, fosse mais remediado, inconstâncias climáticas, evasões de receitas por meio dos descaminhos e intermináveis indefinições jurisdicionais grassavam o cotidiano político-administrativo e econômico da Paraíba. ${ }^{67}$

A respeito do comércio, Castilho fez uma delongada descrição das práticas mercantis na Paraíba, lamentando o fato dos negociantes da cabeça da capitania serem poucos e pobres ${ }^{68}$ Contudo, ao invés de enxergar o ocaso da economia paraibana como fruto perverso do "expansionismo" do vizinho ao sul, como fizera seu antecessor, o capitão-mor culpou a política de monopólios e exclusivos comerciais impulsionada pelo marquês de Pombal a partir da criação das companhias de comércio. $\mathrm{O}$ governador atribuía aos sócios da extinta Companhia Geral de Pernambuco e Paraíba (1759-79), que ainda operavam na praça da cidade, a responsabilidade pelo atraso da agricultura e desânimo das trocas mercantis, reiterando que "a falta de concorrência de compradores opprime o desgraçado lavrador, que não tendo a desgraça de haver obrigado os seus effeitos a dividas carregadas de uzuras mordentíssimas, tem ainda o dado na testa para vender seus effeitos pelos preços correntes, estabelecidos na miséria dos mesmos indivíduos (...)". ${ }^{69}$

$\mathrm{Na}$ visão do governador, o descaminho das produções para o porto do Recife era tão somente o resultado da condição de desalento dos preços provocada pela usura de comerciantes avarentos, o que obrigava os desesperados agricultores da Paraíba a levarem suas fazendas à praça do Recife, a despeito dos altos custos que tinham com tal transporte, tanto por mar quanto por terra. Neste caso, segundo Castilho, Pernambuco e seus agricultores, em proporções até maiores, possuíam quase os mesmos problemas dos "paraibanos", "sendo tal o estado da agricultura que o commercio não só não auxilia, mas tende a extingui-la (...)" ${ }^{70}$ Em sua opinião, apenas a suspensão dos monopólios e a livre circulação modificaria essa funesta condição que prejudicava ambas as capitanias. ${ }^{71}$

O governador também se importou com a administração colonial. Denunciou que os prejuízos ao bom governo se multiplicavam em virtude do estado de subordinação (1756-99). Os efeitos da perniciosa relação administrativa e militar com Pernambuco eram sentidos nos "(...) conflitos de jurisdicção e mando, que (...) estorrão e talves damnão de todo o Real Serviço e o Bem do Público". Freire de Castilho alertava que a oposição e ciúme entre o governador-general e o capitão-mor da Paraíba - uma rivalidade secular, como vimos - "he tanto mais prejudicial quanto mais figurão os subalternos a respeito de quem manda sobre elles (...)" 72 , o que estimulava a impunidade de facínoras que transitavam pelos óbices da lei criados pela anexação. ${ }^{73}$ Doravante na Fazenda, se as cobranças das rendas reais amargavam perdas em virtude dos desvios do Erário e dos percalços com as práticas de dupla tributação, as despesas da Paraíba também pelejavam com a subordinação à Junta da Fazenda de Pernambuco, donde provinham todas as ordens, até em matérias elementares, o que causava dependência e morosidade à gestão. ${ }^{74}$

\footnotetext{
${ }^{67}$ OLIVEIRA, A Paraíba na crise do século XVIII...; ALDEN, Dauril. Late Colonial Brazil (1750-1808). In: Bethell, Leslie (org.). The Cambridge History of Latin America. Cambridge: Cambridge University Press, 1984.

${ }^{68}$ PINTO, Datas e notas para a História da Paraíba..., p. 207.

${ }^{69}$ PINTO, Datas e notas para a História da Paraíba..., p. 208.

${ }^{70}$ PINTO, Datas e notas para a História da Paraíba..., p. 208.

71 "Para que estes males funestíssimos se remedem, cumpre que acuda a Mão Benefica e Poderosa de Vossa Magestade convidando por alguns de tantos meios que tem a Real Grandeza e Poder, negociantes ricos que se estabelecão aqui e possão fazer créditos mais dilatados aos agricultores desta capitania e que mandem vir directamente escravos, effeitos e instrumentos que vendão a mais cômodos preços e isto sem privilégios exclusivos (...)” In: PINTO, Datas e notas..., p. 208.

${ }^{72}$ PINTO, Datas e notas..., p. 211.

${ }^{73}$ Não custa lembrar que, décadas atrás, este mesmo argumento fora utilizado às avessas pelos generais de Pernambuco para defender a anexação da Paraíba, já que, independente, esta constituíra-se em um nicho de facínoras e homiziados que fugiam das rédeas da justiça em Pernambuco. O uso repetido dessa ideia-força ressalta que a anexação não produzira os efeitos positivos quanto ao governo da justiça na região. Cf. PINTO, Datas e notas..., p. 211. A respeito do governo da justiça na Paraíba Setecentista, cf. o estudo de PAIVA, Vivendo à sombra das leis...

74 PINTO, Datas e notas..., p. 211; cf. também AHU_ACL_CU_014, Cx. 33, D. 2409 (ant. 1798, Lisboa); AHU_ACL_CU_014, Cx. 33, D. 2428 (1798, agosto, 1, Paraíba). 
A tese fundamental que decorre dos escritos de Fernando Delgado Freire de Castilho é que a anexação - solução velha adotada em um contexto convulsionado no Império - piorara a saúde geral da administração régia na Paraíba. A Consulta do Conselho Ultramarino, em 1755, não teria sido o resultado de um estudo aprofundado das condições econômicas e fiscais da capitania, mas de uma leitura apressada dos atritos com Pernambuco orientada por um pragmatismo que visou apenas estancar os supostos prejuízos da Fazenda Real com um governo separado. Anexar a Paraíba mostrara-se uma medida simplista e de alto custo político, e nisto o capitão-mor ilustrado concordava com os edis da câmara da Paraíba, quando esbravejaram contra a sujeição em 1756 . Em seguida, a aplicação do instrumental "monopolista" do marquês de Pombal fora insuficiente para dinamizar $e$ aumentar a arrecadação régia, objetivo que, segundo Castilho, só se efetivaria com o livre comércio $e$ com a autonomia governativa.

Doutra feita, como elemento alheio às tramas da política local e à memória dos conflitos entre as duas capitanias, o recém-chegado capitão-mor utilizou argumentos muito distintos para defender um mesmo "fim" que seus antecessores - livrar a Paraíba das garras de Pernambuco. Suas noções de "bom governo" e "bem comum" divergiam dos pedidos por favorecimento de próceres como Jerónimo José de Mello e Castro, ao passo que também não se afinavam com os apelos da elite camarária para que o rei honrasse "a sempre leal cidade da Paraíba", garantindo-lhe os espaços privilegiados como direito natural de conquista e expectativa costumeira de retribuição, conforme a lógica da economia das mercês. ${ }^{75}$

Destarte, mesmo que as velhas práticas de governança permanecessem vivas, as críticas do capitãomor não eram mera retórica, posto que, embasadas em conhecimento empírico à moda da Ilustração, atacavam as principais expressões jurídico-institucionais e socioeconômicas da administração portuguesa à época, como a indisponibilidade das espacialidades, a incoerência das jurisdições, os monopólios comerciais e o recrutamento do corpo de oficiais do Império com base apenas no favorecimento e patrimonialização dos troncos familiares, pouco importando-se com o "Real Serviço e Bem dos Povos". A independência da Paraíba, na defesa de Castilho, não seria, pois, obra dos particularismos e corporativismos do Antigo Regime, mas sim dos princípios de generalidade $e$ racionalidade próprios da reflexão sobre o Estado naquele fim de século. ${ }^{76} \mathrm{Com}$ efeito, a proposta do capitão-mor em quase nada se relacionava com aqueles topoi da cultura política local da Paraíba. $\mathrm{O}$ que pedia Fernando Delgado era que "(...) que Vossa Majestade se digne dar huma nova e particular forma ao governo desta capitania (...)". ${ }^{77}$

Por outro lado, a efêmera, mas substantiva experiência do nativismo das elites senhoriais da cidade da Paraíba, inaugurada no post-bellum, dava sinais claros de cansaço. Exemplo disso fora a acanhada, $e$ até desinteressada resposta da vereação de 1798 ao questionamento de Fernando Delgado Freire de Castilho, que em 12 de abril daquele ano havia ordenado "informasse, pela parte que lhe toca dos prejuízos ou vantagens que esta capitania pode ter no estado de sujeição a de Pernambuco (...)". Na carta-resposta, os edis Luiz Alvarez da Nobrega, Augusto Xavier de Carvalho, Carlos Jorge Monteiro, José Lourenço da Silva e João Gouvea Jasmim não mencionaram em nenhum momento os estratagemas historicamente usados por aquela comunidade local - i.é., que a Paraíba nunca foi de donatário; que a sua cabeça era, por antiguidade e por status de cidade real, superior à Olinda e, sobretudo, ao Recife; que todas as capitanias do Estado do Brasil estavam submissas apenas ao Governo Geral; e que a autonomia da Paraíba, além de ser uma dignidade conferida a súditos que sempre foram confiáveis e leais mesmo diante das maiores provações, forjava um "arauto régio" nas capitanias do Norte diante da instável vassalagem dos "pernambucanos".

O que acontecera? Terá a subordinação de 1756 e a consolidação do hinterland recifense sob a batuta da Coroa finalmente destroçado os focos de resistência? Sem dúvidas, o golpe de 1756 e suas decorrências foram duríssimos para a capital da Paraíba; doutra feita, outros motivos ainda merecem esclarecimento.

\footnotetext{
${ }^{75}$ Sobre a economia das mercês, cf. RAMINELLI, Ronald. Viagens ultramarinas: monarcas, vassalos e governo a distância. São Paulo: Alameda, 2008; e também OLIVAL, Fernanda. As Ordens Militares e o Estado Moderno. Honra, Mercê e Venalidade no Portugal Moderno (1641-1789). Lisboa: Estar Editora, 2001.

${ }^{76}$ PINTO, Datas e notas..., p. 212.

${ }^{77}$ PINTO, Datas e notas..., p. 213, grifos nossos.
} 
Em 1798, a carta da câmara da Paraíba concentrou-se numa defesa "econômica" da separação dos governos, restringindo-se a dizer que "Se no estado de um governo independente nascer nesta capitania um commercio directo, independente de Pernambuco, é de toda a prudente esperança que este Povo posso melhor viver" ${ }^{78}$ Reclamara da falta de suprimentos, a despeito da capitania ser fértil em suas produções, pois tudo era carreado para a vizinha ao sul. Todavia, estiveram ausentes todos os predicativos de precedência, dignidade, hierarquia e lealdade da cantilena gestada pela elite senhorial. A partir daí a contenção do assunto da autonomia da Paraíba apenas nas questões comercial $e$ administrativa, aliás como fizera Fernando Delgado Freire de Castilho em seus relatórios ilustrados à D. Rodrigo de Sousa Coutinho ${ }^{79}$, será, pois, o túmulo daquela emergente identidade local das várzeas do Paraíba.

Paradoxalmente, a defesa da autonomia feita por Fernando Delgado Freire de Castilho fora tomada como elogio à Paraíba e aos paraibanos por boa parte da historiografia do século $\mathrm{XX}$, que não percebera quão apartados eram os fundamentos em que se sustentavam as narrativas da "pátriachica" da cidade da Paraíba e aquela da ilustração liberal de Castilho. A rigor, mesmo quando recuperou relatos do ante-bellum, que apontavam os prejuízos econômicos causados à Paraíba pela proximidade com o porto do Recife, a historiografia tradicional fez de forma deslocada, pois não considerou a real importância da ruptura operada pela guerra de Restauração no seio da açurocracia pernambucana, fragmentando-a política e identitariamente em "nobrezas da terra" espalhadas pelas capitanias do Norte. Essa ruptura decisiva só será analisada a fundo após a obra seminal de Evaldo Cabral de Mello. ${ }^{80}$

A rigor, antes da guerra (ante-bellum), vozes como as de Ambrósio Fernandes Brandão e Diogo de Campos Moreno eram, além de dissonantes, exógenas ao histórico de interações socioculturais e econômicas nutridas até então - como observou brilhantemente Regina Célia Gonçalves - ${ }^{81}$ não sendo, portanto, bons "termômetros" para aferição de uma concorrência entre capitanias e elites locais que só fará sentido quando chegada a hora de repartir o minguado "bolo" do governo local em um contexto de quebradeira e decadência da economia açucareira. Seja como for, às vésperas da Paraíba recobrar a sua independência administrativa, em 1799, parece-nos certo que a rivalidade comercial com o Recife não era mais que um sopro, o que restara daquela identidade local do post-bellum que não se enfrechara apenas em "motivos econômicos", mas que não sobrevivera ao meio século de atuação de uma política régia disposta a "apagar" os particularismos.

Em 17 de janeiro de 1799, uma carta régia livrou a capitania da Paraíba da subordinação em que se achava da de Pernambuco, alegando, dentre outras causas, o aumento populacional como fator primordial para a medida. A decisão de D. Maria I era estendida também ao governo do Ceará, feito independente pela primeira vez. O Rio Grande teve que esperar até 1817. Além dessas providências, a carta de Sua Majestade também ordenava a liberação completa do comércio nas capitanias do Norte, tanto diretamente com o reino (preferível, mas não mais imposto) quanto intercolonial, atendendo então as principais sugestões feitas por Fernando Delgado Freire de Castilho. ${ }^{82}$ Ocioso dizer, e uma qualificada historiografia recente tem confirmado, as relações comerciais no hinterland recifense permaneceram sólidas e duradouras antes e depois da repentina destruição da capitania geral de Pernambuco.

Doutra feita, aquela "pátria-chica" do Antigo Regime português na cidade da Paraíba enfraqueceuse diante da construção de outros sentimentos identitários e de pertencimento mais próprios da modernidade naquela virada de séculos, quando as ideias do liberalismo político e econômico, do individualismo e da racionalização da existência no/para o Estado debelaram progressivamente as antigas culturas políticas e históricas fundadas sobre concepções corporativas, pluralistas e moralreligiosas das comunidades locais na Época moderna. Morrera o nativismo da primeira elite senhorial da várzea do Paraíba, que só seria reinventado como "farsa" pela historiografia do Instituto Histórico e

\footnotetext{
${ }^{78}$ PINTO, Datas e notas..., p. 186.

${ }^{79}$ Para uma análise dos relatórios do Capitão-Mor da Paraíba Fernando Delgado Freire de Castilho, Cf: MENEZES, Mozart Vergetti de \& PAIVA, Yamê Claudino. Ilustração, população e circulação mercantis: a Capitania da Paraíba na virada do século XVIII. In: OLIVEIRA, Carla Mary S.; MENEZES, Mozart Vergetti de; GONÇALVES, Regina Célia. Ensaios sobre a América Portuguesa (org.). João Pessoa: Editora Universitária/UFPB, 2009, p.161-179.

${ }^{80}$ MELLO, Rubro veio...

${ }^{81}$ GONÇALVES, Guerras e açúcares...

${ }^{82}$ PINTO, Datas e notas..., p. 214.
} 
Geográfico Paraibano, no início do século XX.

\section{Epílogo}

Mais de um século após a desanexação de 1799, a historiografia local, notavelmente aquela produção que emanou da influência marcante do Instituto Histórico e Geográfico Paraibano (IGHP) e do seu projeto de escrita da História da Paraíba, imortalizou a personagem emblemática de Fernando Delgado Freire de Castilho, que, além de ganhar o epíteto de "libertador da Paraíba", recebera homenagem como patrono da cadeira 15 daquela casa de memória. Foi imortalizado por ter dado contribuição inigualável à reconquista da autonomia, sonhada há muito pelos "paraibanos".

Pelos idos de 1905, quando a própria República se consolidara, identidades locais da Paraíba buscavam sua "estadualização" no novo arranjo federativo da política nacional. Foi nesse contexto que fora fundado o IHGP, erguido sob os auspícios e influência das obras de Maximiano Lopes Machado (1821-1895) e Irêneo Joffily (1843-1902), escritas nos finais dos Oitocentos. Imbuídos da intenção de desvendar o "espírito paraibano" - entidade transhistórica bem ao estilo do historicismo do século XIX -, a defesa de uma identidade própria à Paraíba e aos paraibanos reassumiu, na pena dos imortais do IHGP, o pendor da separação absoluta da história de Pernambuco. Tendo por fundamento a recuperação do verdadeiro "passado colonial" expresso nas falas de Ambrósio Fernandes Brandão, Fernando Delgado Freire de Castilho e, mais tardiamente, Henrique de B. Rohan, o ímpeto expansionista de Pernambuco foi denunciado como o "eterno inimigo" e a paraibanidade constituída como resistência atemporal. ${ }^{83}$

Entretanto, se as relações políticas, econômicas e sociais entre Paraíba e Pernambuco sempre se mostraram muito tensionadas e complexas, como demonstramos por meio do nativismo da câmara da cidade da Paraíba e seu desejo da criação quase ex-nihilo da capitania, nas defesas de Mathias de Albuquerque contra as investidas de Brito Freire, nas queixas de Jerónimo de Mello e Castro contra a efetivação da subordinação e, enfim, nos relatórios e memórias de governadores dos períodos colonial $e$ imperial quanto a defesa do comércio direto com a Europa, é plausível de verificação uma "razão de continuidade" entre opiniões, julgamentos e decisões tão apartadas pelo tempo sem a imposição de “(...) um padrão falso e sem o recurso à uma prolepse falsa?”, como fez a historiografia do IHGP? ${ }^{84}$

$\mathrm{O}$ que se conhece são, entretanto, os usos políticos que fez dessas narrativas a historiografia tradicional, reunindo-as, quase sempre, a serviço de um propósito ulterior e contextualmente localizado. Foi perante o dito "imperialismo pernambucano" que se expressou o mais agressivo localismo desta historiografia que, consorciada às suas diferentes reverberações, poderíamos tratar como uma cultura historiográfica, no sentido de uma "textura de representações" sobre os passados, para usar uma expressão de Astor Diehl, que abrigou sob seu escopo, articulando atos narrativos de negação, diferenciação e, sobretudo, de esquecimento (memória impedida e/ou memória manipulada). ${ }^{85}$

Muitas vezes a expensas dos rigores da interpretação histórica e da contextualização, a pena de parte significativa dos historiadores do IHGP foi mordaz ao descrever as relações entre Pernambuco $e$ Paraíba, que teriam, desde os primórdios, resultado em prejuízos para essa última. Antônio Freire, sócio efetivo do Instituto em 1979, foi enfático: "A história está cheia de exemplos desde a Colônia até os dias presentes, de que qualquer providência que redunde em benefício para a Paraíba e que dependa de auxílio de Pernambuco, a Paraíba estará perdida". ${ }^{86}$

\footnotetext{
83 "Expansionismo" esse que, segundo a historiografia tradicional vinculada ao IHGP, teria suas raízes históricas na representação do governador de Pernambuco, Duarte Sodré, endereçado à Corte em 1733, sobre as poucas condições da Paraíba em se manter autônoma. A carta encontra-se publicada na Revista do Instituto Histórico e Geográfico Paraibano, v. 6. Paraíba: Imprensa Official, 1935.

${ }^{84}$ Nossa menção aqui é, sem dúvida, a Pocock, que pergunta: "É possível afirmar a continuidade de um debate estendendose por séculos e gerações sem a imposição de um padrão falso e sem o recurso a uma prolepse falsa? Para afirmar que é possível, deve-se ser capaz de demonstrar: 1) a continuidade das linguagens nas quais o debate foi conduzido; e 2) as conexões entre os atos de fala cuja elocução assegurou esse desempenho". POCOCK, J. G. A. Quentin Skinner: a história política e a política da história. Revista Tempo - Revista do Departamento de História da UFF, v.16, n.31, julho/dezembro de 2011.

${ }^{85}$ DIEHL, Astor Antônio. Cultura historiográfica: memória, identidade e representação. Bauru: EDUSC, 2002; ver também RICOEUR, Paul. A memória, a história, o esquecimento. Trad. Alain François [et al]. Campinas: Editora da Unicamp, 2007. ${ }^{86}$ Revista do IHGP..., p. 119.
} 
Não seria demasiado perscrutar o impacto deste primeiro modelo de "como escrever a história da Paraíba" nas futuras gerações de historiadores do estado ao longo do século XX e, numa dimensão mais alargada, na própria gestação desta cultura historiográfica fundamentada sobre visível localismo, com o condicionante do forte viés autonomista frente a um vizinho cujas relações históricas sabiam-se serem indiscutivelmente interligadas, porém desejava-se obliterá-las e, quiçá, negá-las. Como indicativo das indisposições entre as províncias, feitas estados federados em 1889, apresentamos um emblemático discurso de Irêneo Joffily, quando era deputado estadual da Paraíba, antes mesmo da fundação do IHGP.

A Parahyba do Norte é, como algumas províncias do Brasil, sem importância e esquecida de todos, principalmente do Governo. Sujeita a Pernambuco, assim no comércio como Eclesiástica e Juridicamente, compuge-nos vê-la feita quase que uma colônia desta Província. Queremos tratar de seu comércio, lembrando a vantagem de torná-la independente e florescente, de sua agricultura, dos recursos minerais de seus terrenos, de sua autonomia Eclesiástica e Judiciária, e, enfim, de tudo o que lhe possa interessar. Tal é, pois, o motivo principal para que convergem todos os nossos esforços. A nossa política é, especialmente, o bem da Paraíba. Não somos bairristas, mas se apesar de nossa declaração, alguém enxergar bairrismo no que escrevemos, seremos bairristas. ${ }^{87}$

Ocioso dizer que essa historiografia não desconhecia as históricas imbricações com o vizinho ao sul, porém, em virtude de seu projeto de história local, preferiu desmerece-las com preferência de outros usos políticos dos passados sensíveis. Não por menos incorreu em omissões cruciais, como no caso do comércio e da posição particular da capital da Paraíba, que foi pouco compreendida. Como bem lembrou Margarida Dias, "Deixando de lado essa vinculação, desde o seu sentido inicial, com Pernambuco, comprometeu-se as possíveis explicações posteriores sobre o isolamento da Cidade da Paraíba, os problemas do comércio entre o sertão e a cidade do Recife" ${ }^{88}$ Não obstante, além dos contatos entre o sertão paraibano e a praça do Recife, conhecidos desde o período colonial, o conteúdo preciso dos intercâmbios entre a zona da mata da Paraíba e o porto do Recife nos séculos XVII e XVIII, só recentemente ganhou interesse aos olhos de uma historiografia mais recente e menos afeita às mitologias políticas.

De resto, os temas do comércio e das relações políticas com Pernambuco fora sempre um dos assuntos dolorosos da historiografia tradicional - a sua ferida de Narciso. Por isso mesmo, ou foram observados pelos olhares da sórdida subordinação, extraindo das falas dos governadores da Paraíba os discursos em favor da autonomia governativa e do comércio direito com os destinos de exportação, sem intermediação da praça do Recife; ou, simplesmente, uma memória ferida tratou de "esquecer" o assunto, privilegiando outros "mais dignos" ao gênio paraibano. Mas, a nosso ver, o maior prejuízo fora mesmo o anacronismo aplicado à história daquela extinta identidade local vigorosamente ostentada pelos vereadores da Paraíba do post-bellum.

\footnotetext{
${ }^{87}$ JOFFILY, Irêneo. Notas sobre a Parahyba. Fac-similar da primeira edição publicada no Rio de Janeiro, em 1892, com prefácio de Capistrano de Abreu. Brasília: Thesaurus Editora, 1977, grifos nossos.

${ }^{88}$ DIAS, Margarida Maria dos Santos. Intrepida ab Origene. O Instituto Histórico e Geográfico Paraibano e a produção da história local. João Pessoa: Almeida Gráfica e Editora, 1996. 


\section{RESUMO}

$\mathrm{O}$ artigo explora as relações entre as identidades locais do Antigo Regime ibérico e a produção de culturas históricas e culturas políticas na cidade da Paraíba de Nossa Senhora das Neves, entre os séculos XVII e XVIII. Com o fim da guerra da Liberdade Divina e a difícil tarefa de reerguer as capitanias do Norte, repartindo os postos do governo local em um contexto de crise da economia do açúcar, se acentuara a fragmentação e disputa entre as elites senhoriais, todas aparentadas e oriundas do "berço olindense" dos Quinhentos. O acirramento das rivalidades permitiu a eclosão de um emergente sentimento nativista na cidade da Paraíba cujo principal expoente fora o Senado da Câmara e os seus vereadores, inventores de uma toponímia da política local baseada na manutenção dos privilégios $e$ isenções dos "primeiros conquistadores" daquela capitania régia $e$ na defesa da autonomia militar e político-administrativa perante o poderoso vizinho ao sul Pernambuco.

Palavras-chave: Capitania da Paraíba; Identidades locais; Cultura política; Cultura histórica.

\section{ABSTRACT}

The article explores the relationships between the local identities of the Ancient Iberian Regime and the production of historical cultures and political cultures in the city of Paraiba de Nossa Senhora das Neves between the 17th and 18th centuries. With the end of the war of Divine Liberty and the difficult task of rebuilding the captaincies of the North, dividing the local government posts in a context of crisis of the sugar economy, the fragmentation and dispute between the allied lordships, all related and coming from the "Olindense cradle" of the 16th century. The intensification of rivalries allowed the emergence of an emerging nativist feeling in the city of Paraíba, whose main exponent was the "Senado da Câmara" and its councilmen, inventors of a toponymy of the local politics based on the maintenance of the privileges and exemptions of the "first conquerors" of that captaincy and defense of military and political-administrative autonomy before the powerful neighbor to the south Pernambuco.

Keywords: Captaincy of Paraíba; Local identities; Political culture; Historical culture.

Artigo recebido em 05 nov. 2018.

Aprovado em 01 dez. 2018. 
